\title{
THE ROLE OF COST INFORMATION IN DECISION-MAKING. CASE STUDY
}

\author{
Dan Topor ${ }^{1}$ \\ Dorin Ioana ${ }^{2}$ \\ Alina Puțan ${ }^{3}$
}

\begin{abstract}
The purpose of this paper is to understand how information derived from management accounting has an impact on development and foundation of new decisions and therefore to better understand the relationship between management accounting and information. Using as an example a case study from the mining industry we will show the efficiency of information provided by management accounting in decision making and the operational control of the production process.
\end{abstract}

Key Words: Cost, Management Accounting, Information, Expenses.

JEL codes: $M 41$

\section{Introduction}

In our approach we have seen that at the global an national level, researchers (Hamilton, 2003; Albu, 2005; Briciu, 2010) consider that hypercompetition and globalization are two phenomenon that generate complexity in business environment. In this way, it not only creates a state of turmoil and turbulence in the competitive environment and generates changes in market conditions, but also requires changes and developments within the organizations. Organizations around the world are forced to adapt constantly products and services to market demands, to turn their attention to customer satisfaction, manufacturing required sophisticated processes and flexible internal processes that respond quickly to environmental changes.

We can say that, these events leave their mark on the accounting systems of organizations, on the organization and operation of both financial accounting and management accounting.

Interesting approach in the literature (Burns \& Scapens, 2000, Burns \& Baldvinsdottir, 2005, Jarvenpaa 2007, Briciu, 2010) takes a particular interest on these issues and not a few are those who suggest that, because of competition and globalization, extraordinary speed of technology development (e-commerce and internet), privatization and market liberalization, namely the emergence of competition, markets, products and management accounting must change and that accounting information should help organizations to change.

In our opinion, in order to become a counselor and a partner in decision-making management, accounting management should pay particular attention to the costs study (Briciu, 2010). We can say that in Romania the change driven by globalization, increased competition, and the industrialization of production processes have penetrated more slowly. From this point of view, the political and economic context of developing economy, were the factors leading to this effect. So, one should say that the management accounting had a distinct and slowly evolution, compared with the international development. Romanian management accounting is characterized by development, and the modern management methods and tools very well known and internationally used, have appeared in our country. But despite these appearances and changes, there are a few

\footnotetext{
${ }^{1}$ University" 1 December 1918” Alba Iulia, Romania,e-mail: dan.topor@yahoo.com

2 University" 1 December 1918" Alba Iulia, Romania, e-mail: doris.ioana@yahoo.com

${ }^{3}$ University" 1 December 1918” Alba Iulia, Romania,e-mail: putan.alina@yahoo.com
} 
research in this field, rather fragmented that study only the specific technical tools, without making a connection to the organizational context "(Albu, 2005).

Economic entities can operate in an environment that is stable or changeable. In a stable economic environment changes are rare or limited in size and can be easily predicted. If the economic environment is changeable or inconsistent then changes occur frequently, large range with very high influence on the activity of an entity. As a result economic entities take certain decisions taking into account all environmental factors, their intensity and the interaction between action and environmental factors that make up the present and future activities of the entity.

Management accounting plays an important role in the development and substantiation of decisions within an entity because management accounting information helps the manager to answer two important questions: how to allocate resources entrusted by investors to achieve their stated objectives? Respectively, how were used the allocated resources? Michel Capron noted that "under the double effect of competition pressure and the multitude of products and production processes, companies have felt the need to be more aware of costs, to determine as precisely as possible achievable selling prices and margins for each product. It was not only foresight, but it had to be given the means to monitor the implementation of decisions, so it explains the development currently took by management control and its privileged instrument, analytical accounting, which it could not be missed today, by any company. "

\section{Literature review}

The complexity of economic life in conditions of competition imposed by the market economy and globalization also increases the role of information in decision making. Its quality affect both the quality of current decisions and the prospect of taking decisions and hence the results of decision.

The objective of each activity is to increase the efficiency of the basic system, which is why managers need concrete and timely information for decision-making within an entity. From here arises the need to improve management accounting. Accounting information for users fall into one of the categories: public information and / or confidential information.

In countries with a developed market economy the management system of an entity is composed of an information system consisting of applications, concepts and techniques characteristic.

In Anglo-Saxon region, the field of management accounting includes all information "valued" that managers need, and not only information on costs, recognizing that the general subject of management accounting relating to economic resources mobilized not only in their consumption (Briciu S., 2010).

Management accounting is defined in the literature as managerial accounting, analytical accounting (comptabilité analytique) or internal accounting.

Management accounting is that accounting approach of an entity activity that allows separation and structure in subdivisions of property and financial results. In this way you can know how to generate profit or loss in the entity, and ways to influence its activity in order to increase profitability (S. Briciu, 2010).

But a distinction must therefore be made thereby management accounting must include the specific elements of financial accounting (general) and of the second side of accounting, management accounting. A special place in the management accounting must be held by management control, which is responsible for the smooth operation of the informational system necessary in a decision making entity. Also must be included the internal audit, which helps the entity to achieve its objectives, making systematic assessments and improving risk management, control and management processes. 
In France, management accounting is defined "as a technical analysis" of the entity's activities and products manufactured by it having as an objective evaluation of products, works and services and the control of internal conditions of production through costs.

Michel Capron, defines analytical accounting (management - Ed) "as a management tool that is arming the management of an enterprise to meet their information needs and to guide decisions."

In the view of Henri Bouquin management accounting is "an information system that intends to help managers and influence behavior by modeling the relationship between resources consumed and aims pursued".

Henri Bouquin (2004) believes that "the major role of management accounting is to produce information to enable modeling the relationship between resources deployed and the results obtained in return."

Another definition of management accounting we discover at the U.S. National Association of Accountants (NAA) which defines management accounting as "the identification, measurement, collection, analysis, preparation, interpretation and transmission of financial information used by management of an enterprise for planning, evaluation and control of appropriate and responsible use of its resources."

Chartered Institute of Management Accountants UK (CIMA) explain management accounting as "Management accounting is an integral part of management dealing with the identification, presentation and interpretation of information used for: the formulation of strategies, planning and control of activities, decision-making; the use of resources, information of members and other external information users, information of workers, protection of assets. "

Management process is based on a wealth of information taken from the area of management accounting. As part of this information a very important role in the management of economic entities is the concept of cost and presenting it in different structures or different levels of responsibility.

Planning the future activities of an entity, decisions that managers take within the entities (purchasing decisions, pricing decisions) are closely related to knowledge of costs. Cost accounting has a huge impact on the quality of decisions made by managers.

Ebbeken et al. define cost as "an expense or an amount of expenditure associated with (and recognized) a resource consumption, a place of business, a product produced or reporting period".

Bernard Y, Colli J.C. (1994), define cost as "amount expressed in general in currency, of the necessary expenditure for the purchase or production of a good or service."

According to specialists Glautier M. and Underdown B. (2001) "cost is the monetary expression of the effort that an entity must do to achieve its objectives. "

In the Anglo-Saxon literature there is consensus on the definition of cost, the cost is defined as an indicator of monetary sacrifice made to obtain and provide customer specific products or services, achieving a work or performance of an activity.

Cost information is valuable in decision-making process to ensure the achievement of a production, an activity with a reasonable cost by eliminating waste and production factors which translate into greater efficiency.

\section{Research methodology}

The research may be defined as a search through a methodological process of improving your own knowledge and those of others by the discovery of nontrivial facts and visions. The necessary condition for achieving success in research domain is adding new knowledge in this domain.

The scientific research could be defined as a process of expansion of knowledge, achieved through a careful and objective observation, investigation, experimentation and targeting the discovery of new information or interpretation. 
In a philosophical approach, there are two main types of research: empirical and theoretical, and from the functional point of view, the research can be divided into basic research (pure) and applied research.

The researchers supporter of the constructivism in dealing with the scientific knowledge have as objective to explain a reality, which means that this is a construction based on a reality likely to be explained. Positivists use the empirical testing, ensuring the presentation of the reality and being sure that this knowledge is the only one that deserves to be considered scientific knowledge.

In this research activity, I suggest both a descriptive and empirical research on believing that such objectives will be achieved. Also, the paper proposes a descriptive and explanatory approach, because the research will explain certain mechanisms, concepts and in the same time some solutions will be offered simultaneously.

In our study we called as research methods the document analysis, the observation and the case study. We consulted specialized literature, etc., articles, publications. In the last part of our work we tried to present conclusions following the analysis of conducted study.

\section{Possible use of management accounting information in management optimization}

To run a process of knowledge as an activity carried out in conditions at least satisfactory is necessary to know the systematic way in which this takes place, in order to assess at intervals as short as how the conditions set out initially to be involved with most promptly to eliminate negative deviations, as appropriate, to correct the default provisions. The process of operational knowledge becomes increasingly difficult as the complexity of the system increases, we appreciate that as we progress in research exponentially information asymmetry is growing in terms of selection of the relevant information.

Any specific organization or any distinct activity has a feature information system which should provide complete information of the body in sufficient quantities, fair and at the level of efficiency required by consumers of information.

Therefore we believe that the information system is under the base system object or system, or in other words, economic and social body and the two entities have a common goal, namely the continuous growth of the basic efficiency of system.

Accounting for the economic information system is both a data source and one of its basic components.

In making decisions accounting must be understood as an information system that allows the production and dissemination of information for necessary decisions.

The market economy creates problems which targets maximum satisfaction of customers needs, with minimal income, on the one hand and manufacturer profit maximization, with minimal production expenses, on the other.

We belive that by using information, managers can controle entity's activity on each field and can act on it in real time. In terms of modern activities, information becomes very important within the entities.

Management (leadership or training decision) includes all the decisions, regulations, decisions and other measures taken by the governing bodies to meet the bodies subordinate to their duties to achieve the objectives of an entity. Control function involves the exercise of their duties appropriate bodies and persons authority, and providing each employee motivation in these tasks. With the adoption of management decisions should be provided staff training in its execution.

Manager must be able to define what information it requires and needs, and the entity's information system must be able to provide the information it needs.

It is obvious that strong connection between management and accounting information comes from the fact that the work requires detailed knowledge and permanent management structure and size of funds and resources. 
Objective of each activity is to increase the efficiency of basic system, which is why managers need timely information as concrete as possible for decision-making within an entity. From here it starts the necessity of improving management accounting. Accounting information for users fall into the categories: public information and / confidential information.

Because competition is becoming stronger entities can survive in conditions that obtain quality, timely, vital and real-time accounting information on the situation of heritage, analytical results, market relations with business partners, competition, suppliers.

After integrating domestic market size is an advantage no longer stimulant, which transfers the competition for foreign direct investments in terms of cost. Foreign investment increased competition after the horizontal integration of products offered by local producers.

Additional expenses in implementing the legislation, norms and European standards for taxation, environmental, quality or marking products were reflected in the final price of Romanian products and services, which increased the competitive pressure exerted by European Union products.

Entities must consider the growth of economic efficiency, through covering the costs and making profit. For investments entities may be supported by appealing to national programs and structural funds.

\section{The information in the context of mining industry}

In terms of the management team, information that substantiates a pertinent decision is the one in which it blends the accuracy and speed of entity extraction from sleep mode of the entity.

Here we wish to present a model that encompasses the main elements substantiating the decisions in terms of activities of an entity from the Economy and Commerce Ministry namely a subunit of SNLO (National Society of Lignite Oltenia).

The model requires daily tracking of income and main costs arising from operating activities of lignite from surface quarries. The model is developed and implemented for a period of 12 months by authors at quarry Prigoria.

The module contains the main items of income and cost involved in the production process for each working point.

Structural the module contains two elements involved: incomes and expenses.

Each component highlights program element and daily and cumulative element made in relation to each other.

Both the revenue and expense side are watched daily on each working point, allows the general manager access to real information during the production process, information that helps in making decisions before the completion of production.

In terms of components, we follow the material costs, costs representing over $70 \%$ of the income made to obtain preliminary and final economic result (profit or loss).

Another important component of the production process is the economic agent with which the economic entity has a relationship of services, transport, supply, the safeguarding heritage, etc. Daily tracking "activity on the workstation" gives managers the opportunity to act on schedule slippages from the beginning of the production process

Currently we managed to implement this module in two mining units, economic units that have a monthly turnover of 22,680.00 lei. 
DAILY SITUATION OF PRODUCTION ACHIEVING THE MAIN ELEMENTS OF INCOME AND COSTS FROM B.V.C JANUARY 1, 2011

\begin{tabular}{|c|c|c|c|c|c|c|}
\hline \multirow{3}{*}{ INDICATORS } & \multirow{3}{*}{ U.M. } & \multicolumn{5}{|c|}{ QARRY PRIGORIA } \\
\hline & & \multirow{2}{*}{$\begin{array}{c}\text { Project } \\
\text { BVC } \\
\end{array}$} & \multicolumn{2}{|c|}{ ACCOMPLISHED } & \multirow{2}{*}{ DIF } & \multirow{2}{*}{$\%$} \\
\hline & & & DAY & CUMULATIVE & & \\
\hline 1 & 2 & 3 & 4 & 5 & $6=5-3$ & $7=5 / 3$ \\
\hline Physical production & mii $\mathbf{t}$ & 380 & 15,00 & 40,00 & $-340,00$ & $\mathbf{1 0 , 5 3}$ \\
\hline Production delivered & mii t & 380 & 10,01 & 29,91 & $-350,09$ & $\mathbf{7 , 8 7}$ \\
\hline Uncovered & mii mc & 2.460 & 39,00 & 123,50 & $2.336,50$ & 5,02 \\
\hline Mass mining & $\operatorname{mii}(\mathbf{m c}+\mathbf{t})$ & 2.840 & 54,00 & 163,50 & $2.676,50$ & 5,76 \\
\hline Report uncovered & mc/to & 6,47 & 2,60 & 3,09 & $-3,39$ & 47,69 \\
\hline Production of goods (wholesale price) & mii lei & 23.039 & 900 & 2.400 & -20.639 & 10,42 \\
\hline Wholesale price & lei/to & 60,63 & 60,00 & 60,00 & $-0,63$ & 98,96 \\
\hline Total income $(1+2+3)$ & mii lei & 23.498 & 835 & 2.269 & -21.229 & 9,66 \\
\hline 1. Operating revenue, which : & mii lei & 23.498 & 835 & 2.269 & -21.229 & 9,66 \\
\hline a) production sold & mii lei & 23.039 & 835 & 2.269 & -20.771 & $\mathbf{9 , 8 5}$ \\
\hline d) Capitalized production & mii lei & 416,63 & $\mathbf{0}$ & $\mathbf{0}$ & -417 & \\
\hline - directing their own investments & mii lei & 417 & & & -417 & $\mathbf{0 , 0 0}$ \\
\hline - others income & mii lei & & & & $\mathbf{0}$ & \#DIV/0! \\
\hline e)Other operating revenue, of which: & mii lei & 42 & $\mathbf{0}$ & $\mathbf{0}$ & -42 & $\mathbf{0 , 0 0}$ \\
\hline - other operating income & mii lei & 41,67 & $\mathbf{0}$ & $\mathbf{0}$ & -42 & $\mathbf{0 , 0 0}$ \\
\hline A. MATERIAL COSTS & mii lei & $6.731,44$ & 264 & 1.227 & -5.505 & 18,23 \\
\hline 1. Raw materials, of which: & mii lei & 912,51 & 43,83 & 656,26 & -256 & 71,92 \\
\hline - for extra lanes & mii lei & $\mathbf{0}$ & & $\mathbf{0}$ & $\mathbf{0}$ & \\
\hline - for mechanical works, including: & mii lei & 755,00 & 43,83 & 645,76 & -109 & 85,53 \\
\hline
\end{tabular}




\begin{tabular}{|c|c|c|c|c|c|c|}
\hline - for extra lanes & mii lei & & & & $\mathbf{0}$ & \\
\hline - for. electrical works, of which: & mii lei & 101,60 & $\mathbf{0 , 0 0}$ & $9, \mathbf{5 0}$ & -92 & 9,35 \\
\hline - for extra lanes & mii lei & & & & $\mathbf{0}$ & \\
\hline $\begin{array}{l}\text { - for production + administrative + sales + work } \\
\text { protection }\end{array}$ & mii lei & 55,91 & $\mathbf{0 , 0 0}$ & $\mathbf{1 , 0 0}$ & -55 & 1,79 \\
\hline 2. Recoverable materials & mii lei & $\mathbf{0}$ & & & $\mathbf{0}$ & \\
\hline 3. Fuel & mii lei & 65,00 & $\mathbf{0 , 0 0}$ & 6,30 & -59 & 9,69 \\
\hline 4. Energy and water & mii lei & $2.810,00$ & 122,17 & 258,49 & -2.552 & 9,20 \\
\hline 5. Other material expenses $(a+b+c+d+e)$ & mii lei & $2.943,93$ & 98,23 & 305,84 & -2.638 & 10,39 \\
\hline a) Maintenance and repairs & mii lei & 556,74 & $\mathbf{0}$ & $\mathbf{0}$ & -557 & $\mathbf{0 , 0 0}$ \\
\hline - maintenance, overhaul and repair mechanic & mii lei & 519,00 & & & -519 & $\mathbf{0 , 0 0}$ \\
\hline - maintenance, overhaul and electric repairs & mii lei & 35,00 & & & -35 & $\mathbf{0 , 0 0}$ \\
\hline - others expenses & mii lei & 2,74 & & & -3 & $\mathbf{0 , 0 0}$ \\
\hline $\begin{array}{l}\text { b) Goods and freight transportation service + } \\
\text { interest }\end{array}$ & mii lei & 228,86 & 12 & 36 & -193 & 15,77 \\
\hline - goods and freight transportation & mii lei & 214,78 & 11,60 & 34,30 & -180 & 15,97 \\
\hline - transport for business & mii lei & 14,08 & $\mathbf{0 , 6 0}$ & $\mathbf{1 , 8 0}$ & -12 & 12,78 \\
\hline c) Services provided to businesses, including: & mii lei & $2.105,99$ & 86 & 258 & -1.848 & 12,24 \\
\hline - economic agents, of which: & mii lei & $1.385,99$ & 57,00 & 171,00 & -1.215 & 12,34 \\
\hline - equipment & mii lei & 639,00 & 30,80 & 83,00 & -556 & 12,99 \\
\hline - with SNLO units & mii lei & 720,00 & 29 & 87 & -633 & 12,05 \\
\hline d) Rents of fixed assets & mii lei & 45,67 & $\mathbf{0}$ & $\mathbf{1 0}$ & -36 & 21,90 \\
\hline e) Other expenses & mii lei & 6,67 & $\mathbf{0}$ & 2 & -5 & 29,99 \\
\hline
\end{tabular}


The structure contains a comparative reporting (percentage values) between BVC (the income and expenses budgets) and daily accomplishments, so with a very small margin of error the manager succeeds to control the material costs involved in the production process.

Quick access to economic information enables better distribution of resources and at the same time eliminating unnecessary expenses, expenses that affect the cost of production and the performance of automated decision within the entity.

The project presented above can be implemented more widely in the analysis performed in order to sustain the relevant decision, and here we talk about "planning", so the strategy has two aspects:

- a design strategy

- follow-up strategy and implementation

In conclusion we can not talk about pertinent decision without strategy and no strategy can be implemented without information and economic information comes to us through demodulation accounting activities, so we consider management accounting as a base of decisions in the economical process of the entity.

I

\section{Conclusions}

Throughout this paper we analyzed the existing concepts and approaches in economic literature and practice of management accounting, management control and accounting of the costs and tried to start a model of management accounting well founded and practical applicable.

We appreciate that by starting to build this system and by implement it into a entity we achieved the objectives we had when we started research but also are aware that when the system will be used by others accountants many improvements will be found.

Analyzing the model above, we consider that this management accounting system could be implemented in many entities, not only entities from the mining industry. With appropriate adjustments to their own situation, the system would lead to further information for decision makers and to a better organization of their work. In any productive economic entity it should be pursued with great care value for economic efficiency, which means making products more competitive as the price to be accepted by the market, in terms of costs as low as possible to ensure economic efficiency.

The level of product quality and its price determines the cost, quality and cost is possible with a very strong relationship, based on which one can determine the extent to which the added value as a result of improving the quality justifies the cost increase.

We are already working at a new improved material named "intelligent management procedure", which will improve the level of information that managers will use in making decisions and of course can be adapted to others industrial activities. This will be the subject of a future research paper.

Manager decisions, based on the relation between the information provided by Management Accounting and Financial Audit, which manager can ask in a special decision council for crisis periods and economical stagnation, can lead to the decrease of possible errors from accounting information which are offered by financial situations, information that are behind pertinent decisions. 


\section{References}

1. Achim S.A., 2009. Accounting for managers, Risoprint Publishing, Cluj-Napoca

2. Albu N., Albu C., 2003. Performance management tools, Economica Publishing, Bucharest

3. Albu C., 2005. An analysis of organizational learning through valuing managerial accounting tools, $\mathrm{PhD}$ thesis, ASE Bucharest

4. Aslău T., 2001. Management control beyond appearances, Economica Publishing, Bucharest.

5. Atrill P., McLaney E., 2005. Management Accounting for Decision Makers, Harlaw, Englad, New York: Prentice/ Financial Times

6. Ahrens T., Chapman C.S., Hopwood A.G., 2007. Handbook of Management Accounting Research, Oxford, Elsevier

7. Ahrens T., Chapman C.S., 2007. Management accounting as practice. Accounting, Organizations and Society, volume 32, Pages 1-27

8. Bouquin, H., 2004. Management accounting, translation and introductory study made by professor N.Tabără, Moldova Publishing, Iaşi.

9. Bouquin, H., 2004. Management accounting, Tipo moldova Publishing, Iaşi

10. Bouquin H, 2006. Comptabilité de gestion, Paris, Economia, $3^{\mathrm{e}}$ éd.

11. Briciu S., 2006. Managerial accounting. Theoretical and practical aspects, Economica Publishing, Bucharest

12. Briciu S., 2008. Variable and fixed costs in company management: Annales Universitatis Apulensis Series Oeconomica, 10(1), pp.: $164-170$

13. Briciu S., Căpuşneanu S., Rof L., Topor D., 2010. Accounting and management control. Tools for measuring the performance on an entity, Aeternitas Publishing, Alba Iulia.

14. Burns J., Scapens R., 2000. Conceptualising management accounting change: an institutional framework, Management Accounting Research, Vol. 11, No. 1;

15. Burns J., Baldvinsdottir G., 2005. An institutional perspective of accountants' new roles - the interplay of contradictions and praxis, European Accounting Review, Vol. 14, No. 4

16. Capron M., 1994. Accounting in perspective, Humanitas Publishing, Bucharest

17. Caraiani C., Dumitrana M., (coord), 2005. Management accounting \& Management control, InfoMega Publishing, Bucharest

18. Călin O. (coord.), 2002. Management accounting, Tribuna Economică Publishing House, Bucharest

19. Căpuşneanu S., 2008. Elements of cost management, Economica Publishing, Bucureşti

20. Chapman C., 2005. Controlling strategy. Management accounting and performance measurement, oxford, Oxford University Press

21. Chenhall R., 2003. Management control system design within its organizational context: Findings from contingency-based research and directions for the future, Accounting, Organizations and Society, 28(2-3), pp. 127-168

22. Colasse B., Lesage C., Tabără N., 2011. Introduction in accounting, Tipo Moldova Publishing, Iaşi.

23. Diaconu P., 2002. Managerial accounting, Economica Publishing, Bucharest

24. Drury C., 2006. Cost and Management Accounting,Thomson Learning

25. Ebbeken K., Possler L., Ristea M., 2000. Calculation and cost management, Teora Publishing, Bucharest

26. Fatacean G., 2009. Managerial accounting, Cluj-Napoca.

27. Garrison R. H., Noreen E.W., Brewer P., 2009. Managerial Accounting, McGraw-Hill-Irwin

28. Grosanu A, 2010. Cost calculation on profit centers, Irecson Publishing, Bucharest. 
29. Hamilton B., 2003. How to be a top strategic advisor, Strategic Finance (June)

30. Herath S.K., 2007. A framework for management control research, Journal of Management Development, Vol. 26 No. 9, pp. 895-915

31. Horvath \& Partners, 2007. Controlling. Sisteme eficiente de creştere a performantei firmei, Editura C.H. Beck, București

32. Ionaşcu I., Filip A.T., Stere M., 2006. Control de gestiune, IInd edition, Economică Publishing House, Bucharest.

33. Iosivan O.R., 2010. Auditing in Europe - Evolution and trends, Revista Economică, no. 6(53), vol.II

34. Ivan O.R., 2009. European Standardization of Audit, Annals of the University of Petrosani, Economics, Volume 9, Issue 4

35. Jarvenpaa M., 2007. Making business partners: A case study on how management accounting culture was changed, European Accounting Review, Vol. 16, No. 1

36. Tabără N., 2009. Management control, Tipo Moldova Publishing, Iaşi

37. Verboncu I., Zalman M., 2005. Management and performances, Universitara Publishing, Bucharest

38. Weetman P., 2006. Management Accounting, Prentice Hall, Harlow

39. Zimmerman J., 2002. Accounting for Decision Making and Control, McGraw-Hill/Irwin

40. www.revista.cafr.ro;

41. http://www.jstor.org

42. www.springerlink.com

43. www.oxfordjurnals.org 